\title{
Co-creating a Legal Check-up in a School-based Health Center Serving Low-income Adolescents
}

\author{
Lisa Kessler \\ Georgetown University Law Center, Lisa.Kessler@georgetown.edu \\ Yael Cannon \\ Georgetown University Law Center, yc708@georgetown.edu \\ Nicole Tuchinda \\ University of Memphis Cecil C. Humphreys School of Law \\ Ana Caskin \\ MedStar Georgetown Division of Community Pediatrics \\ Christina Balz Ndjatou \\ MedStar Georgetown Division of Community Pediatrics
}

See next page for additional authors

This paper can be downloaded free of charge from:

https://scholarship.law.georgetown.edu/facpub/2398

https://ssrn.com/abstract=3890231

Copyright () 2021 Johns Hopkins University Press. This article first appeared in Progress in Community Health Partnerships: Research, Education, and Action, 15:2 (2021), 203-216. Reprinted with permission by Johns Hopkins University Press.

This open-access article is brought to you by the Georgetown Law Library. Posted with permission of the author. Follow this and additional works at: https://scholarship.law.georgetown.edu/facpub

Part of the Civil Rights and Discrimination Commons, Health Law and Policy Commons, and the Law and Society Commons 


\section{Authors}

Lisa Kessler, Yael Cannon, Nicole Tuchinda, Ana Caskin, Christina Balz Ndjatou, Vicki W. Girard, and Deborah F. Perry

This article is available at Scholarship @ GEORGETOWN LAW: https://scholarship.law.georgetown.edu/facpub/2398 


\section{Co-creating a Legal Check-up in a School-based Health Center Serving Low-income Adolescents}

Lisa Kessler, $\mathrm{MBA}^{1}$, Yael Cannon, JD ${ }^{1}$, Nicole Tuchinda, JD², Ana Caskin, $\mathrm{MD}^{3}$, Christina Balz Ndjatou, CRNP ${ }^{3}$, Vicki W. Girard, JD ${ }^{1}$, and Deborah F. Perry, $\mathrm{PhD}^{4}$

(1) Georgetown University Law Center; (2) University of Memphis Cecil C. Humphreys School of Law; (3) MedStar Georgetown Division of Community Pediatrics; (4) Georgetown University Center for Child \& Human Development

Submitted 21 February 2020, revised 14 December 2020, accepted 15 January 2021

Abstract

The Problem: Marginalized populations experience healthharming legal needs-barriers to good health that require legal advocacy to overcome. Medical-legal partnerships (MLPs) embed lawyers into the healthcare team to resolve these issues, but identifying patients with health-harming legal needs is complex, and screening practices vary across MLPs.

Purpose of Article: Academic and community partners who collaborate in an MLP at a school-based health center (SBHC) share their process of co-creating a two-stage legal check-up for adolescents.

Key Points: Screening adolescents for health-harming legal needs is challenging. It took ongoing collaboration to refine the process to fit the needs of adolescents and meet the partners' goals.

Conclusion: Social determinants of health play a significant role in health disparities, and there is a need for innovative solutions to screen and address these in vulnerable populations. Other partners can learn from our experiences to cocreate their own approach to addressing health-harming legal needs.

\section{Keywords}

Academic-community partnerships, Screening, Social determinants of health, Interdisciplinary collaboration, Medical-legal partnership, Adolescent health
S ocial determinants of health, the factors of daily life related to where people live, work, learn, play, and age, have a profound impact on the health and well-being of marginalized populations and contribute to health disparities. ${ }^{1}$ One subset of social determinants of health includes "healthharming legal needs," ${ }^{2}$ which are unmet legal needs that create barriers to good health that require legal advocacy to overcome. Medical-legal partnerships (MLPs) address health-harming legal needs by integrating lawyers into healthcare teams to provide legal services to patients. For example, a child with asthma may not respond to treatment unless legal advocacy is used to force the property owner to remediate mold and mildew exacerbating her condition. While identifying patients' health-harming legal needs is a critical MLP function, how they do so varies widely. A National Center for MLP survey found that many MLPs do not use a formal screening tool or follow consistent screening practices. ${ }^{3}$

As a new MLP serving adolescents, we wanted to improve uniformity of patient screening for unmet legal needs. This article describes how our MLP collaborated to design and implement a two-stage "legal check-up" specially tailored for screening adolescents. We hope other MLP partners, especially those working with adolescents, will benefit from our approach and the tools we created. We also hope that our co-creation process will guide other partnerships that want to develop intentional, tailored approaches to screening patients for health-harming legal needs. 
CREATING THE PARTNERSHIP

The Health Justice Alliance Law Clinic at Georgetown University Law Center launched in August 2017, with the goals of training students to work in an MLP and providing free legal services to low-income, marginalized patients served by Georgetown's academic health center partner, MedStar Health. The Law Clinic leadership team, composed of law faculty and teaching fellows, a research director, and an operations director, had preliminary conversations with several departments providing care to underserved patients in Washington, DC. Among these was MedStar Georgetown University Hospital's School-Based Health Center (SBHC) at Anacostia High School (Anacostia). SBHCs allow students in under-resourced, lowincome communities to access primary care at clinics in or near their schools. ${ }^{4}$ Anacostia's SBHC medical director was an early champion for bringing the MLP model to her patients and their families. At Anacostia, 97\% of students are Black and 81\% are considered "at risk," defined as receiving income supports for low-income families, experiencing homelessness, in foster care, or at least one year older than the expected grade age. ${ }^{5}$ The SBHC team, composed of the medical director/pediatrician, nurse practitioner, nurse, and patient services coordinator, had previously attempted to connect families to civil legal aid providers when legal emergencies arose. However, barriers such as lack of transportation and limited intake hours often prevented families from following up.

The partners anticipated challenges in bringing the MLP model to Anacostia, including that adolescents receive care without their parents present and may lack direct knowledge of their families' unmet legal needs. However, they committed to working through these challenges together. The SBHC felt they could not effectively care for their patients without addressing their health-harming legal needs, and the legal team valued the opportunity to offer legal representation in a trusted setting to families that would otherwise be unable to access it. The legal team received assurance from the SBHC team that they could connect effectively with parents and other caregivers, which they were already accustomed to doing in the course of caring for patients. The SBHC team also explained their developmentally appropriate approach of asking adolescents about challenges at home and school without a parent present so adolescents could answer honestly. ${ }^{6}$ The SBHC team felt that even if adolescents might not recognize a problem as a legal one, they could help identify the symptoms of a potential unmet legal need, such as mold in their apartment. The legal team knew of two other MLPs embedded in SBHCs (one in the Chicago area, ${ }^{7}$ and one in Oakland, California ${ }^{8}$ ), which demonstrated precedent for integrating the MLP and SBHC models.

Over the course of a year, the partners laid the groundwork for the MLP, a key aspect of which was determining how to screen and refer patients for unmet legal needs. To accommodate their different professional perspectives, expertise, experiences, and obligations, the partners committed to cocreating and implementing the program. The Health Justice Alliance had seed funding from Georgetown, which included protected time for the SBHC medical director to help establish the MLP.

\section{IDENTIFYING LEGAL NEEDS}

The partners first identified the legal needs SBHC patients and their families were likely to experience. The legal team drew on their experience representing low-income families and adolescents, results from a community listening project that surveyed low-income D.C. residents about access to justice gaps in the city, ${ }^{9}$ and a legal needs assessment conducted by law students in an MLP seminar. The students grounded that assessment in publicly available data about Anacostia High School and the surrounding neighborhood. The SBHC team contributed their decade of experience from caring for patients and interacting with families. The partners concluded that patients were likely to face: inadequate access to public benefits and healthcare; unstable housing and poor housing conditions; educational struggles including suspension/ expulsion, lack of access to educational supports, and bullying; living with a non-parent caregiver; and teen pregnancy and parenting issues.

\section{DESIGNING A SCREENING APPROACH}

Having engaged cooperatively to identify potential legal needs, among the first co-creation challenges for the MLP was the legal team's preference to formally screen every patient for unmet legal needs. The legal team saw that as necessary to generate sufficient cases for the Law Clinic and to accelerate understanding of how to maximize impact for the SBHC population. However, the SBHC team's approach to screening 
was to peak a patient's interest in discussing a particular concern rather than adhering to a formal diagnostic tool. The SBHC team cautioned that adolescents might require more context and support from the provider to help understand how a lawyer could be an advocate for their family, and to feel comfortable sharing issues they were facing at home. The partners compromised by deciding to design and implement a screening tool covering the array of issues adolescents might face, which the provider could then discuss with the patient.

\section{EVOLUTION OF THE SCREENING TOOL}

To inform the design of the screening tool, the partners reviewed available legal needs screening tools and consulted with other SBHC and MLP practitioners. This included attending a conference presentation by the SBHC in Oakland, California at the National Center for MLP Summit. The Oakland team stressed the challenges of talking about sensitive issues with adolescents, the importance of limiting the number of screening questions, tailoring questions so that adolescents could feasibly answer them, and advised integrating legal needs screening into existing health clinic flows and processes. ${ }^{10}$ The partners also spoke with staff at the national School-Based Health Alliance, who directed them to a screening tool comparison chart. ${ }^{11}$ The partners reviewed these screening tools, as well as the National Center for MLP's Legal Needs Screener Toolkit, which includes a "pick list" of screening questions in the Income, Housing and Utilities, Education and Employment, Legal Status, and Personal and Family Stability (I-HELP) domains. ${ }^{12}$ The partners also relied on Children's Law Center's Advocacy Code Card, ${ }^{13}$ which includes questions pediatricians can ask to identify potential unmet legal needs.

Reviewing these tools informed the partners' process, but as none were specifically designed for screening adolescents for health-harming legal needs, the teams ultimately drafted new questions and adapted others. The result was a form with thirteen questions grouped into three categories: "Public Benefits, Health Insurance and Housing"; "Education"; and "Family." Consistent with trying to peak patient interest and avoid missing potential legal issues, some questions included multiple topics. For example, "Are you pregnant or parenting and you need help with getting childcare; health insurance such as Medicaid; child support from the other parent; or public benefits such as food stamps, TANF, or WIC?" Others were broader, such as "In the past 2 months have you or anyone you know had problems having a stable place to live?"

The SBHC team tested the tool for a few months, gathered feedback from patients and then regrouped with the legal team to discuss progress and challenges. One issue was survey fatigue; patients had to complete multiple forms as part of their visits and would either not finish the questionnaire or inaccurately check "yes" to each prompt. Patients also often asked the nurse to clarify questions. The legal team reported receiving fewer referrals than they had expected, given the challenges facing the patient population.

To address these issues, the SBHC nurse practitioner suggested fewer, more concise screening questions might be sufficient to start a conversation with patients about legal needs. The partners also worked to narrow the scope of the screening tool to address only areas where the legal team felt they could be most effective:

- Patients not receiving appropriate educational services or struggling to access education because of homelessness, pregnancy, or parenting issues ${ }^{14}$;

- Patients cared for primarily by a non-biological parent without legal authority to make medical, educational or other decisions for the patient ${ }^{15}$;

- Patients or their families facing public benefits denials, terminations, or reductions ${ }^{16}$;

- Patients living without basic utilities or in housing with unhealthy conditions (e.g., mold, lead paint, pests, etc.) $)^{17}$; and

- Patients facing food insecurity. (Although not always a legal issue, the partners agreed that food insecurity is often an indicator of more complex public benefits issues requiring advocacy.) $)^{16}$

During this stage, the legal team did an additional review of existing screening tools, in hopes of identifying or rediscovering validated questions targeting these specific legal issues. The partners used the American Academy of Pediatrics' Screening Tool Finder to find other screenings that covered education, financial security/stress, food insecurity, and housing. ${ }^{17}$ The team identified four additional relevant tools-WE CARE, PRAPARE, Accountable Health Communities, and Health Leads-and compared questions from each in the domains of interest to the partners (Table 1). ${ }^{18-22}$ 


\begin{tabular}{|c|c|}
\hline \multicolumn{2}{|r|}{ EDUCATION } \\
\hline WE CARE ${ }^{18}$ & $\begin{array}{l}\text { Do you have a high school degree? } \\
\square \text { Yes } \\
\square \text { No } \\
\text { If NO, would you like help to get a GED? } \\
\square \text { Yes } \\
\square \text { No } \\
\square \text { Maybe Later }\end{array}$ \\
\hline PRAPARE $^{19}$ & $\begin{array}{l}\text { What is the highest level of school that you have finished? } \\
\square \text { Less than high school degree } \\
\square \text { High school diploma or GED } \\
\square \text { More than high school degree } \\
\square \text { I choose not to answer this question }\end{array}$ \\
\hline $\begin{array}{l}\text { Accountable } \\
\text { Health Communities }{ }^{20}\end{array}$ & $\begin{array}{l}\text { Do you want help with school or training? For example, starting or completing job } \\
\text { training or getting a high school diploma, GED or equivalent. } \\
\square \text { Yes } \\
\square \text { No }\end{array}$ \\
\hline Health Leads ${ }^{21}$ & $\mathrm{~N} / \mathrm{A}$ \\
\hline IHELLP 22 & $\begin{array}{l}\text { Please indicate which of the following (if any) describe a problem with your child's } \\
\text { education. } \\
\square \text { A child of mine is receiving special education services and has an Individualized } \\
\text { Education Plan (IEP) but it is not working well (e.g., not being followed, IEP doesn't } \\
\text { address needs, or student repeatedly suspended/expelled). } \\
\square \text { A child of mine is struggling in school (e.g., at risk of failing, repeatedly } \\
\text { suspended/expelled or being held back) and is not getting special education services } \\
\square \text { I have requested a special education evaluation ("multifactored evaluation") that may } \\
\text { lead to an IEP but the school has not responded }\end{array}$ \\
\hline \multicolumn{2}{|r|}{ THIRD PARTY CUSTODY } \\
\hline WE CARE & $\mathrm{N} / \mathrm{A}$ \\
\hline PRAPARE & $\mathrm{N} / \mathrm{A}$ \\
\hline $\begin{array}{l}\text { Accountable } \\
\text { Health Communities }\end{array}$ & $\mathrm{N} / \mathrm{A}$ \\
\hline Health Leads & $\mathrm{N} / \mathrm{A}$ \\
\hline IHELLP & $\begin{array}{l}\text { Do you have guardianship or custody issues? } \\
\square \text { Yes } \\
\square \text { No }\end{array}$ \\
\hline \multicolumn{2}{|r|}{ PUBLIC BENEFITS \& HEALTH INSURANCE } \\
\hline WE CARE & N/A \\
\hline PRAPARE & $\begin{array}{l}\text { What is your main insurance? } \\
\square \text { None/uninsured } \\
\square \text { Medicaid } \\
\square \text { CHIP Medicaid } \\
\square \text { Medicare } \\
\square \text { Other public insurance (not CHIP) } \\
\square \text { Other public insurance (CHIP) } \\
\square \text { Private Insurance }\end{array}$ \\
\hline
\end{tabular}


Table 1. (continued)

\begin{tabular}{|c|c|}
\hline $\begin{array}{l}\text { Accountable } \\
\text { Health Communities }\end{array}$ & $\mathrm{N} / \mathrm{A}$ \\
\hline Health Leads & $\mathrm{N} / \mathrm{A}$ \\
\hline IHELLP & $\begin{array}{l}\text { Please indicate which of the following describe a concern you have about your income or } \\
\text { benefits. You may select none or more than one answer. } \\
\square \text { Medicare/Medicaid/Health Insurance } \\
\square \text { Disability benefits } \\
\square \text { Family First } \\
\square \text { Supplemental Nutrition Assistance Program (SNAP) / Special Supplemental } \\
\text { Nutrition Program for Women, Infants and Children (WIC) } \\
\square \text { Unemployment benefits/compensation } \\
\square \text { Child support } \\
\square \text { Pension } \\
\square \text { Other }\end{array}$ \\
\hline \multicolumn{2}{|r|}{ HOUSING } \\
\hline WE CARE & $\begin{array}{l}\text { Do you think you are at risk of becoming homeless? } \\
\square \text { Yes } \\
\square \text { No } \\
\text { If YES, would you like help with this? } \\
\square \text { Yes } \\
\square \text { No } \\
\square \text { Maybe Later }\end{array}$ \\
\hline PRAPARE & $\begin{array}{l}\text { What is your housing situation today? } \\
\square \text { I have housing } \\
\square \text { I do not have housing (staying with others, in a hotel, in a shelter, living outside on the } \\
\text { street, on a beach, in a car, or in a park) } \\
\square \text { I choose not to answer this question } \\
\text { Are you worried about losing your housing? } \\
\square \text { Yes } \\
\square \text { No } \\
\square \text { I choose not to answer this question }\end{array}$ \\
\hline $\begin{array}{l}\text { Accountable } \\
\text { Health Communities }\end{array}$ & $\begin{array}{l}\text { Think about the place you live. Do you have problems with any of the following? } \\
\text { CHOOSE ALL THAT APPLY } \\
\square \text { Pests such as bugs, ants, or mice } \\
\square \text { Mold } \\
\square \text { Lead paint or pipes } \\
\square \text { Lack of heat } \\
\square \text { Oven or stove not working } \\
\square \text { Smoke detectors missing or not working } \\
\square \text { Water leaks } \\
\square \text { None of the above }\end{array}$ \\
\hline Health Leads & $\begin{array}{l}\text { Are you worried that in the next } 2 \text { months, you may not have stable housing? } \\
\square \text { Yes } \\
\square \text { No }\end{array}$ \\
\hline
\end{tabular}

(table continues) 


\begin{tabular}{|c|c|}
\hline IHELLP & $\begin{array}{l}\text { Please indicate which of the following describe a problem(s) with your housing situation. } \\
\text { You may select none or more than one answer } \\
\square \text { Bugs (e.g., roaches) or rodents } \\
\square \text { General cleanliness } \\
\square \text { Landlord disputes } \\
\square \text { Lead paint } \\
\square \text { Unreliable utilities (e.g. electricity, gas, heat) } \\
\square \text { Medical condition that makes it difficult to live in current house } \\
\square \text { Mold or dampness } \\
\square \text { Overcrowding } \\
\square \text { Threat of eviction } \\
\square \text { Other }\end{array}$ \\
\hline \multicolumn{2}{|r|}{ UTILITIES } \\
\hline WE CARE & $\begin{array}{l}\text { Do you have trouble paying your heating bill for the winter? } \\
\square \text { Yes } \\
\square \text { No } \\
\text { If YES, would you like help with this? } \\
\square \text { Yes } \\
\square \text { No } \\
\square \text { Maybe Later }\end{array}$ \\
\hline PRAPARE & $\begin{array}{l}\text { In the past year, have you or any family members you live with been unable to get any of } \\
\text { the following when it was really needed? Check all that apply. } \\
\square \text { Food } \\
\square \text { Utilities } \\
\square \text { Clothing } \\
\square \text { Child Care } \\
\square \text { Medicine or Any Health Care (Medical, Dental, Mental Health, Vision) } \\
\square \text { Phone } \\
\square \text { Other (please write): } \\
\square \text { I choose not to answer this question }\end{array}$ \\
\hline $\begin{array}{l}\text { Accountable } \\
\text { Health Communities }\end{array}$ & $\begin{array}{l}\text { Think about the place you live. Do you have problems with any of the following? } \\
\text { CHOOSE ALL THAT APPLY } \\
\square \text { Pests such as bugs, ants, or mice } \\
\square \text { Mold } \\
\square \text { Lead paint or pipes } \\
\square \text { Lack of heat } \\
\square \text { Oven or stove not working } \\
\square \text { Smoke detectors missing or not working } \\
\square \text { Water leaks } \\
\square \text { None of the above }\end{array}$ \\
\hline Health Leads & $\begin{array}{l}\text { In the last } 12 \text { months, has your utility company shut off your service for not } \\
\text { paying your bills? } \\
\square \text { Yes } \\
\square \text { No }\end{array}$ \\
\hline
\end{tabular}




\begin{tabular}{|c|c|}
\hline IHELLP & $\begin{array}{l}\text { Please indicate which of the following describe a problem(s) with your housing situation. } \\
\text { You may select none or more than one answer } \\
\square \text { Bugs (e.g., roaches) or rodents } \\
\square \text { General cleanliness } \\
\square \text { Landlord disputes } \\
\square \text { Lead paint } \\
\square \text { Unreliable utilities (e.g. electricity, gas, heat) } \\
\square \text { Medical condition that makes it difficult to live in current house } \\
\square \text { Mold or dampness } \\
\square \text { Overcrowding } \\
\square \text { Threat of eviction } \\
\square \text { Other }\end{array}$ \\
\hline \multicolumn{2}{|r|}{ FOOD INSECURITY } \\
\hline WE CARE & $\begin{array}{l}\text { Do you always have enough food for your family? } \\
\square \text { Yes } \\
\square \text { No } \\
\text { If NO, would you like help with this? } \\
\square \text { Yes } \\
\square \text { No } \\
\square \text { Maybe Later }\end{array}$ \\
\hline PRAPARE & $\begin{array}{l}\text { In the past year, have you or any family members you live with been unable to get any of } \\
\text { the following when it was really needed? Check all that apply. } \\
\square \text { Food } \\
\square \text { Utilities } \\
\square \text { Clothing } \\
\square \text { Child Care } \\
\square \text { Medicine or Any Health Care (Medical, Dental, Mental Health, Vision) } \\
\square \text { Phone } \\
\square \text { Other (please write): } \\
\square \text { I choose not to answer this question }\end{array}$ \\
\hline $\begin{array}{l}\text { Accountable } \\
\text { Health Communities }\end{array}$ & $\begin{array}{l}\text { Within the past } 12 \text { months, you worried that your food would run out before you got } \\
\text { money to buy more. } \\
\square \text { Often true } \\
\square \text { Sometimes true } \\
\square \text { Never true } \\
\text { Within the past } 12 \text { months, the food you bought just didn't last and you didn't have } \\
\text { money to get more. } \\
\square \text { Often true } \\
\square \text { Sometimes true } \\
\square \text { Never true }\end{array}$ \\
\hline Health Leads & $\begin{array}{l}\text { In the last } 12 \text { months, did you ever eat less than you felt you should because there } \\
\text { wasn't enough money for food? } \\
\square \text { Yes } \\
\square \text { No }\end{array}$ \\
\hline IHELLP & N/A \\
\hline
\end{tabular}


This exercise again confirmed that the available screening questions were not a good fit for the SBHC setting and the particular legal needs they wanted to target. For example, Accountable Health Communities ${ }^{20}$ included a housing question with a long list of issues to check-off that we knew based on our first version was an overwhelming format for adolescents. The existing tools also often required the patient to have knowledge that adolescent patients were unlikely to possess, such as about utility bills or interactions with property owners. In the education domain, questions were aimed at adult caregivers, so the team customized a question designed to unearth adolescents' own educational concerns.

The partners worked together to create a simplified question for each domain, knowing that providers could delve further into some of the nuances with patients in follow-up dialogue. For example, the first version of our third party custody question read: "Is someone other than your parent (such as a grandparent, aunt, or uncle) the main person taking care of you AND he or she may want help getting the legal ability to make decisions about your education, health care, or housing?" We simplified this question to: "Are you being cared for by a grandparent or other family member or friend?" We removed the separate section of questions for pregnant and parenting adolescents, because many of them were redundant to other questions on the form.

To increase patients' comprehension, we incorporated images to signal the question topic, and ran the questions through a literacy check. We also altered the introductory language on the form, removing the specific mention of lawyers and adding language to clarify that the goal of the screening was to identify where patients might need extra support and connect them to assistance. (Figure 1 provides our original and revised screening tools.)

In the summer of 2019, we conducted a preliminary validation of the screening tool. We reviewed the screening results for 99 patients in relation to their health outcomes in their electronic medical record. The data suggested that the screening tool was able to identify clients with clinically significant issues around education, nutrition, and behavioral health. ${ }^{24}$

\section{EVOLUTION OF THE CLINICAL APPROACH}

The SBHC providers embedded the screening into their clinical workflow. After taking patients to the exam room, the nurse, who has high visibility and trust with the patient population, would introduce the screening form by stating, "this clinic works with a team of lawyers and law students that may be able to provide you or your family free and confidential legal services. We are asking all patients to complete a screening for legal needs. Your answers to these questions can help us see whether legal services could help you or your family." Patients were then given time to complete the form independently. For patients screening positive for any legal need, the nurse then shared the form with the medical provider seeing the patient that day. The provider would talk with the patient to get a better understanding of the problem, address any questions about the role of the lawyer, and reach out to the patient's family about a referral if the patient consented (in many situations, the patient's caregiver or parent was the potential client in need of legal assistance). With the family's permission, the provider would make a referral to the legal team.

After a few months of using this approach, the SBHC team noted that there was overlap between their conversations with patients about legal needs and the Bright Futures ${ }^{25}$ questions they reviewed with patients at well visits. Bright Futures is an American Academy of Pediatrics health promotion initiative and framework for well-child care. For each well-child visit, Bright Futures includes questions on priority topics related to a child or adolescent's social, developmental and physical health for the provider to review with the patient and their family. At the SBHC, the providers review the questions and enter the adolescent's responses into the electronic health record. The SBHC also hosts medical students and residents on rotation, and the SBHC team felt they needed more formal guidance for these learners. To avoid duplication and add additional supports for providers, the partners developed materials to guide providers' conversations with patients about specific legal needs, in the context of the Bright Futures framework (Figure 2). This approach also fit well with the simplified screening tool, as providers could ask more questions about a range of legal issues not specifically named on the screening form.

First, the pediatrician and legal team linked each legal need covered by the screening form to a Bright Futures question, and the legal team drafted follow-up questions that providers could ask to identify a legal need. For example, 


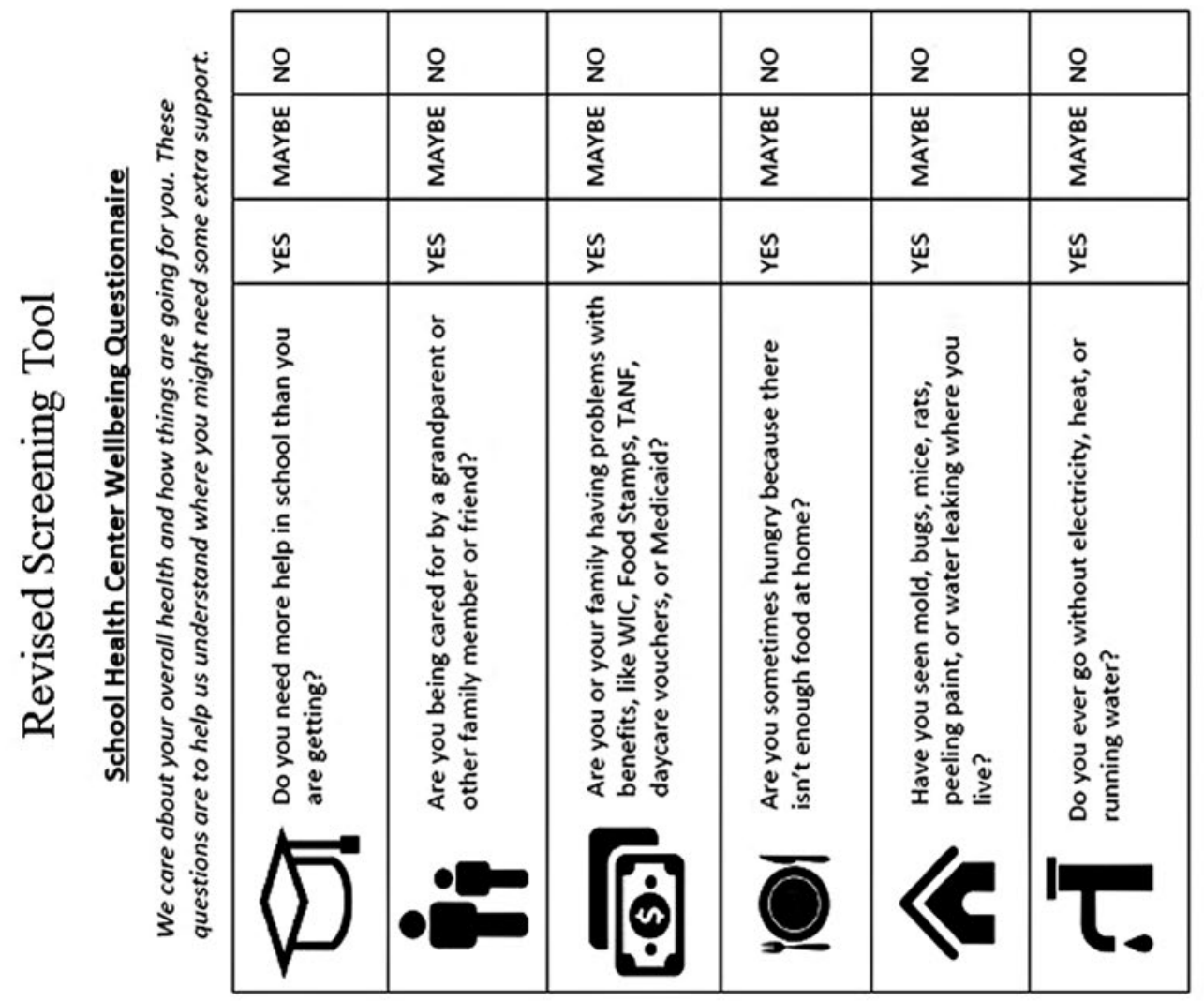

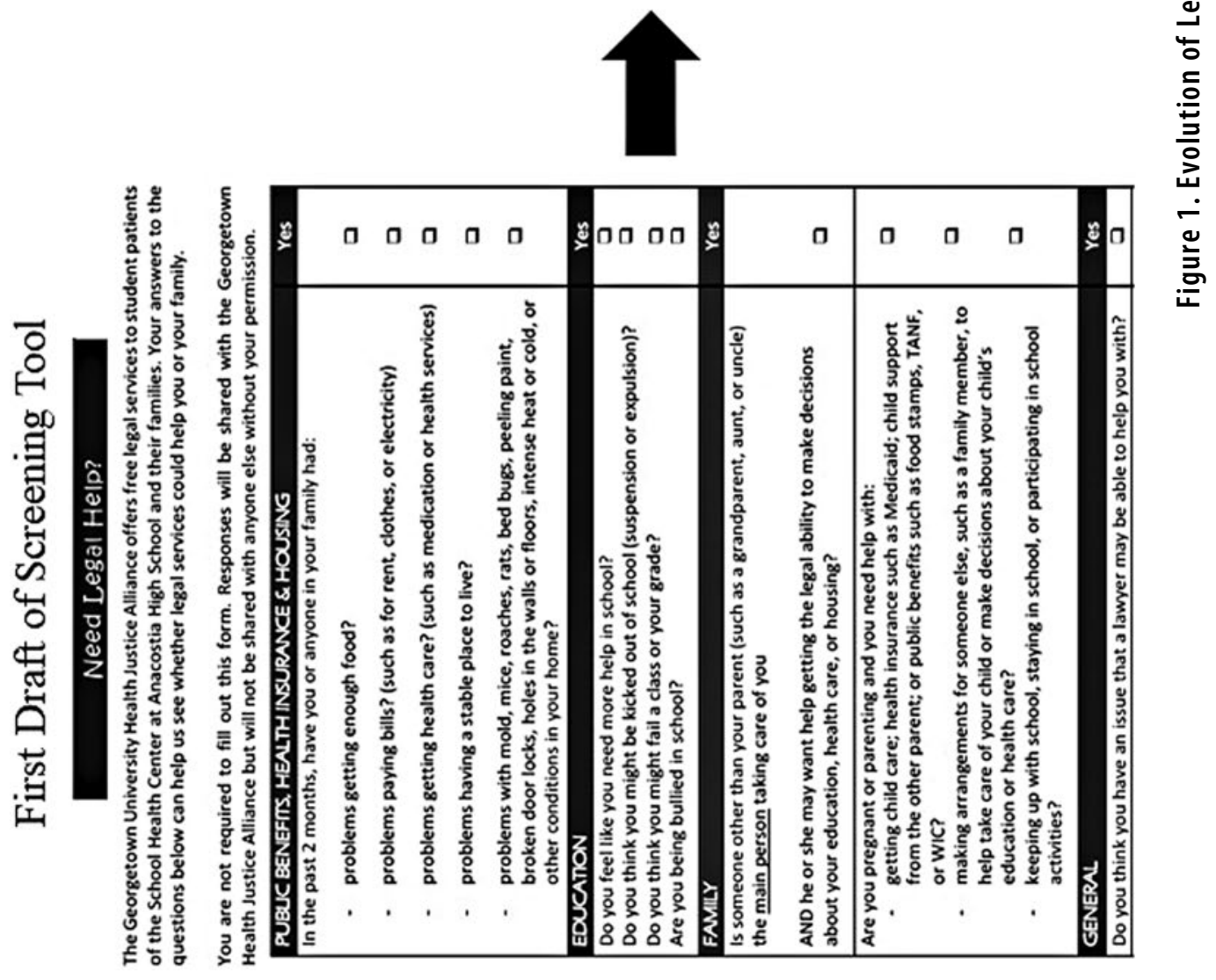



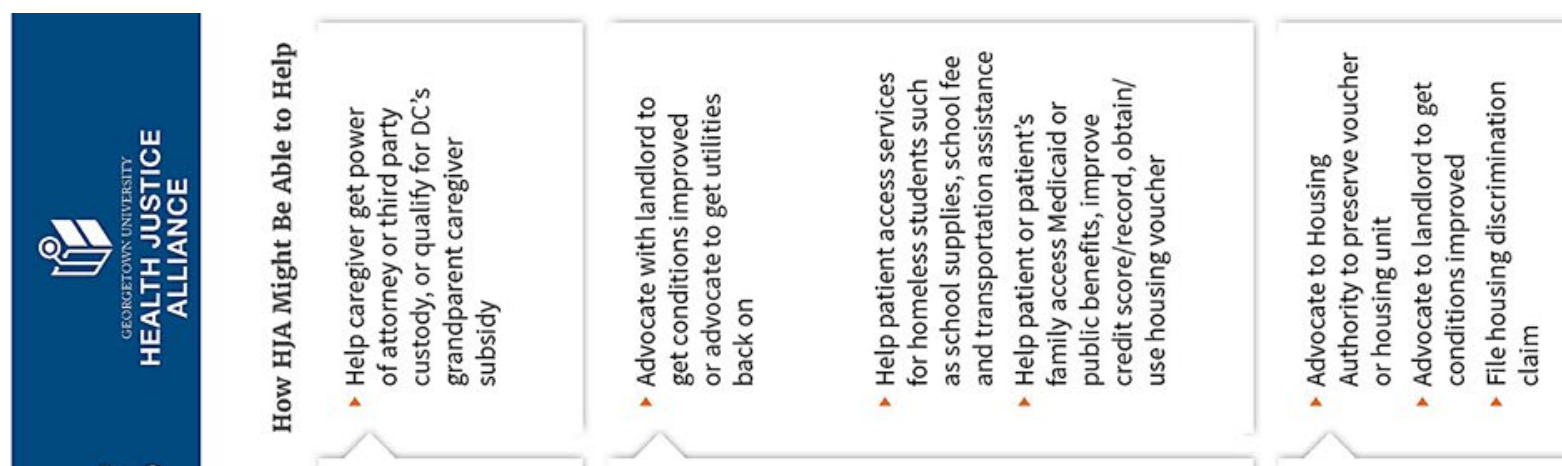

(2)
(1)
(1)
U
(1)
(1)
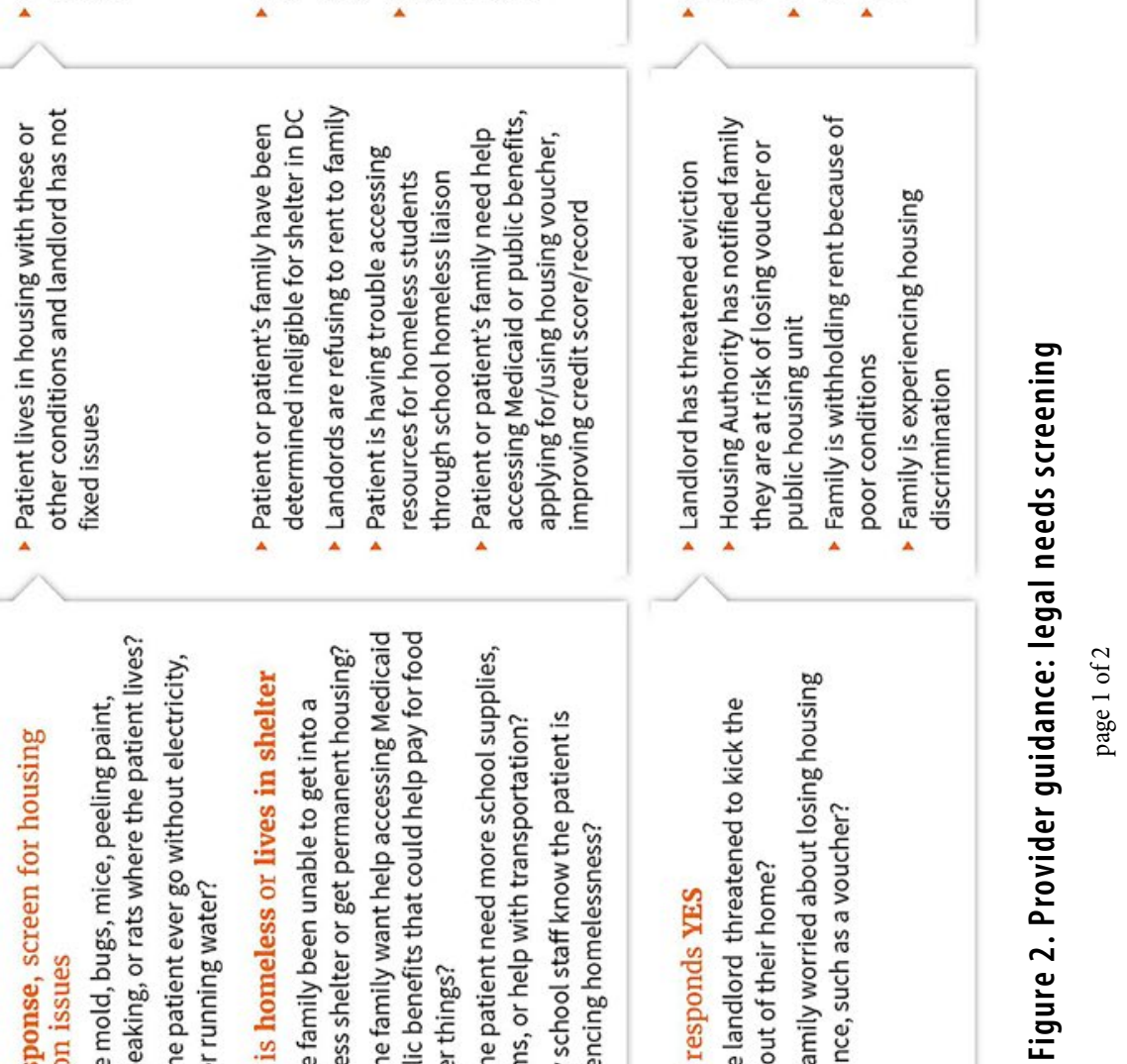


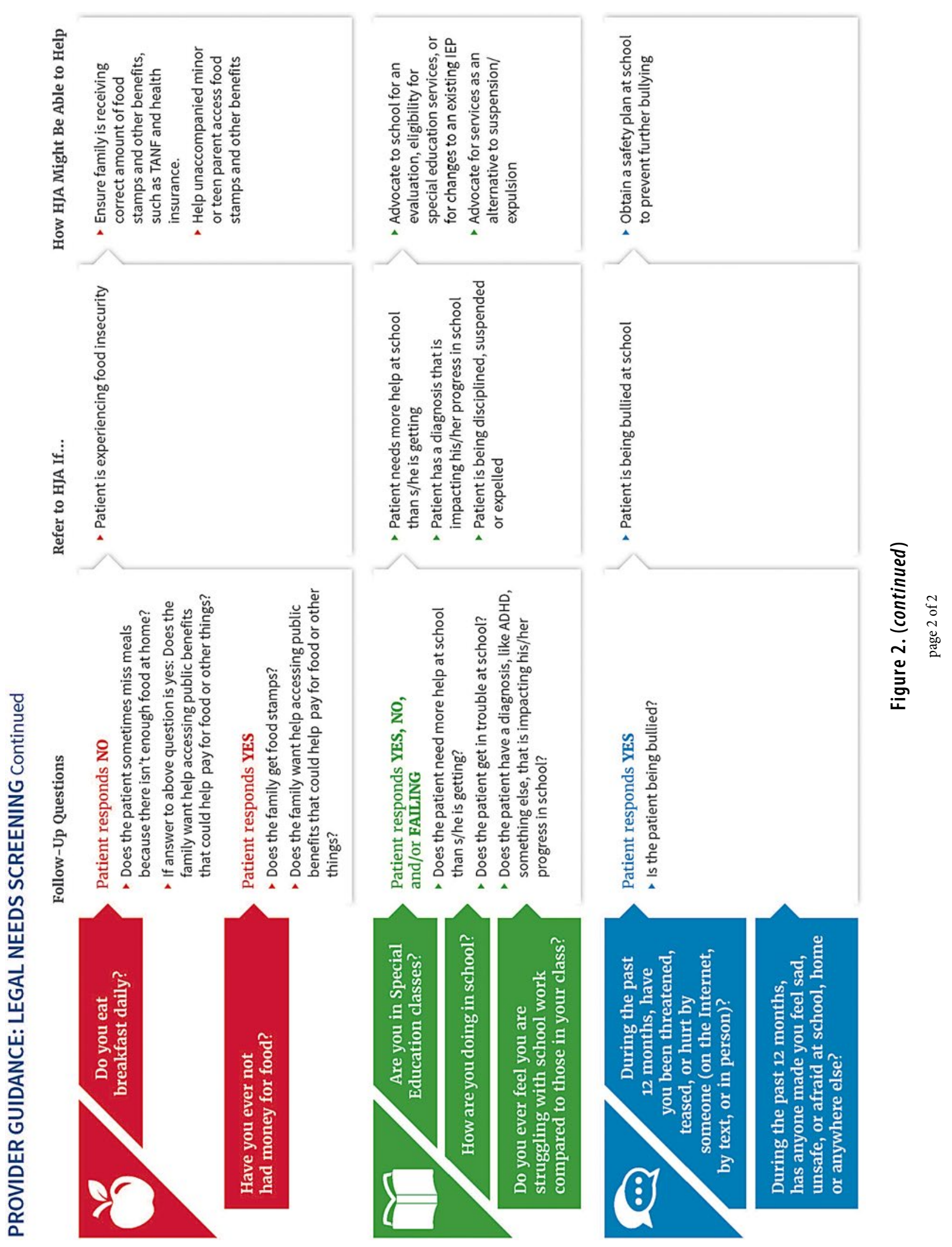


one Bright Futures question is, "Who do you live with?" This question on its face is not about legal issues, but if the patient responds that they are living with someone other than their mother or father, a provider can ask follow-up questions to identify any third party custody issues. The legal team also generated examples of when a referral to the legal team would be most appropriate and how the legal team could intervene. Together the partners organized the information into a chart, and had it formatted by a graphic designer to make it visually appealing and easy to read. The SBHC team placed a framed chart on the desk in each exam room for easy reference.

\section{THE VALUE OF A TWO-STAGE APPROACH}

The SBHC providers found that a two-stage approach where patients complete the screening tool independently and providers engage in follow-up discussions using the Bright Futures chart allowed for a more effective screening process. A patient's responses to the screening tool helped providers identify what domains the patient might be struggling with, and where to focus their conversations as they subsequently worked through the Bright Futures questions during the course of each visit. The providers also noted that sometimes patients' responses on the form would contradict their verbal responses to the Bright Futures questions, which would give the provider the opportunity to explore the discrepancy and identify where patients might be struggling. Overall, SBHC providers report that the co-creation of the screening form combined with the education for framing follow-up conversations around health-harming legal needs has resulted in an effective process for screening and referrals of patients with unmet legal needs. Likewise, the legal team saw a corresponding improvement in the healthcare team's capacity to screen, identify, and refer patients with unmet legal needs to the law clinic.

\section{LESSONS LEARNED}

The partners co-created an approach to identifying the health-harming legal needs of adolescents and their families. Related literature on screening adolescents for the broader category of social determinants of health validates our learnings: tailor screening questions specifically to adolescents; keep the screening short; integrate screening into the electronic health record and other clinical assessment processes; allow patients to complete screening independently; and support clinicians in determining where to refer patients. ${ }^{26,27}$

A two-stage legal check-up is especially valuable with populations that may have negative views of lawyers or are reluctant to share their challenges for fear of negative consequences. Asking patients to complete the screening on their own allowed patients to be more honest, and helped providers focus on the most pressing issues in their patients' lives. Providers benefited from the additional resources we developed to have these conversations with patients.

The process of co-creating an effective screening approach took significant time and effort. While the academic partners had this as part of their funded work, community partners may not have the same flexibility. We were able to allocate resources to ensure protected time for our medical champion, which supported the iterative work that resulted in our success. Partners should budget for brainstorming, testing and revising the tool as well as protected time, if possible. After we completed our process, we learned of the Social Interventions Research \& Evaluation Network screening tool inventory, ${ }^{28}$ which may help other collaborators to identify appropriate screening tools more quickly (Table 2).

Given the significant role that social determinants of health play in health disparities, there is a need for innovative solutions to screen and address these in vulnerable populations. We hope our experiences will serve as a model for others seeking to reduce health inequities for low-income, marginalized communities. 


\begin{tabular}{|c|c|c|}
\hline \multicolumn{3}{|c|}{$\begin{array}{l}\text { Table 2. Tools We Considered that SIREN }{ }^{29} \text { also Includes in Its Inventory, as Well } \\
\text { as Additional Tools SIREN Lists, for the Domains of Interest to our Team }\end{array}$} \\
\hline Domain & $\begin{array}{l}\text { Tools Compiled by Health } \\
\text { Justice Alliance and SIREN }\end{array}$ & Additional Tools SIREN Lists \\
\hline Education & $\begin{array}{l}\text { Accountable Health Communities } \\
\text { IHELLP }{ }^{\mathrm{a}} \\
\text { PRAPARE } \\
\text { WE CARE }^{\mathrm{a}}\end{array}$ & $\begin{array}{l}\text { AAFP Social Needs Screening Tool } \\
\text { AccessHealth Spartanburg Screening Tool } \\
\text { Boston Medical Center-Thrive Screening Tool } \\
\text { HealthBegins Upstream Risk Screening Tool } \\
\text { National Academy of Medicine Domains } \\
\text { Structural Vulnerability Assessment Tool } \\
\text { WellRx Toolkit } \\
\text { Kaiser Permanente's Your Current Life Situation Survey }\end{array}$ \\
\hline Third-party custody & IHELLP $^{a}$ & Kaiser Permanente's Your Current Life Situation Survey \\
\hline Public benefits and health insurance & $\begin{array}{l}\text { IHELLP }^{a} \\
\text { PRAPARE } \\
\text { WE CARE }^{a}\end{array}$ & $\begin{array}{l}\text { Structural Vulnerability Tool } \\
\text { Boston Medical Center-Thrive Screening Tool } \\
\text { Health Leads } \\
\text { Kaiser Permanente's Your Current Life Situation Survey }\end{array}$ \\
\hline Housing & $\begin{array}{l}\text { Accountable Health Communities } \\
\text { Health Leads } \\
\text { IHELLP }^{\mathrm{a}} \\
\text { PRAPARE } \\
\text { WE CARE }^{\mathrm{a}}\end{array}$ & $\begin{array}{l}\text { AAFP Social Needs Screening Tool } \\
\text { Arlington Screening Tool } \\
\text { Boston Medical Center-Thrive Screening Tool } \\
\text { HealthBegins Upstream Risk Screening Tool } \\
\text { Total Health Assessment Questionnaire for Medicare Members } \\
\text { North Carolina Medicaid Screening Tool } \\
\text { Structural Vulnerability Assessment Tool } \\
\text { WellRx Toolkit } \\
\text { Kaiser Permanente's Your Current Life Situation Survey }\end{array}$ \\
\hline Utilities & $\begin{array}{l}\text { Accountable Health Communities } \\
\text { Health Leads } \\
\text { IHELLP }^{\mathrm{a}} \\
\text { PRAPARE } \\
\text { WE CARE }^{\mathrm{a}}\end{array}$ & $\begin{array}{l}\text { AAFP Social Needs Screening Tool } \\
\text { Arlington Screening Tool } \\
\text { Boston Medical Center-Thrive Screening Tool } \\
\text { North Carolina Medicaid Screening Tool } \\
\text { WellRx Toolkit } \\
\text { Kaiser Permanente's Your Current Life Situation Survey }\end{array}$ \\
\hline Food insecurity & $\begin{array}{l}\text { Accountable Health Communities } \\
\text { Health Leads } \\
\text { PRAPARE } \\
\text { WE CARE }^{\text {a }}\end{array}$ & $\begin{array}{l}\text { AAFP Social Needs Screening Tool } \\
\text { AccessHealth Spartanburg Screening Tool } \\
\text { Arlington Screening Tool } \\
\text { Boston Medical Center-Thrive Screening Tool } \\
\text { HealthBegins Upstream Risk Screening Tool } \\
\text { Total Health Assessment Questionnaire for Medicaid Members } \\
\text { North Carolina Medicaid Screening Tool } \\
\text { Structural Vulnerability Assessment Tool } \\
\text { WellRx Toolkit } \\
\text { Kaiser Permanente's Your Current Life Situation Survey } \\
\text { SEEK Parent Questionnaire } \\
\text { Survey of Well-Being of Young Children }\end{array}$ \\
\hline
\end{tabular}

${ }^{a}$ Designed specifically for use in pediatric settings. 
1. Office of Disease Prevention and Health Promotion. Social determinants of health [cited 2020 Feb 20]. Available from: https://www.healthypeople.gov/2020/topics-objectives/topic/ social-determinants-of-health

2. Cohen E, Fullerton DF, Retkin R, Weintraub D, Tames P, Brandfield J, et al. Medical-legal partnership: Collaborating with lawyers to identify and address health disparities. J Gen Intern Med. 2010 May;25(Suppl. 2):136-9.

3. Theiss J, Regenstein M. Facing the need: Screening practices for the social determinants of health. J Law Med Ethics 2017; 45(3):431-41.

4. Love HE, Schlitt J, Soleimanpour S, Panchal N, Behr C. Twenty years of school-based health care growth and expansion. Health Affairs. 2019 May;38(5):755-64.

5. Anacostia High School Profile. DC Public Schools [cited 2020 Oct 5]. Available from: https://profiles.dcps.dc.gov/ Anacostia+High+School

6. Goldenring JMRD, Rosen DS. Getting into adolescent heads: An essential update. Contemp Pediatr. 2004;21:64-90.

7. Fact sheet: School-based health and medical-legal partnerships [updated 2019; cited 2020 Oct 5]. Available from: https://medical-legalpartnership.org/mlp-resources/school -based-health/

8. Morse J. How School-based health centers have become a lifeline for East Bay immigrants. Rewire News Group [updated 2017; cited 2020 Oct 5]. Available from: https://rewirenews group.com/article/2017/11/28/school-based-health-centers -become-lifeline-east-bay-immigrants/

9. Mullen F, Pumar E. The Community Listening Project. The DC Consortium of Legal Services Providers [updated 2016; cited 2020 Oct 16]. Available from: www.lawhelp.org/files/7C92C43F -9283-A7E0-5931-E57134E903FB/attachments/A4B5C44F -8B88-4B76-97A9-FF648F7C7EB9/clp-final-april-2016.pdf.

10. Bauer J, Phillips M, Shore A. Just health-School based MLPs to address social determinants of health [Conference presentation]. National Center for Medical-Legal Partnership 2017 Summit, National Harbor, Maryland.

11. Moore S. Social determinants of adolescent health: Screening students for community needs. School-Based Health Alliance [updated 2016; cited 2019 Nov 11]. Available from: www.sbh4all.org/2016/10/social-determinants-of-adolescent -health-screening-students-for-community-needs/

12. MLP legal needs screening tool available for download. National Center for Medical-Legal Partnership [updated 2015; cited 2019 Nov 13]. Available from: https://medical-legal partnership.org/screening-tool/

13. Advocacy Code Card. Children's Law Center. Available from: www.childrenslawcenter.org/sites/default/files/Advocacy $\% 20$ Code\%20Card\%20f\%26b.pdf

14. Tames P, Curran M, Senft S, Needlman R. Education: Connecting health and quality learning opportunities. In: Tobin Taylor E, Lawton E, Conroy K, et al, editors. Poverty, health and law: Readings and cases for medical-legal partnership. Durham (NC): Carolina Academic Press; 2011. p. 275-314.
15. Rodabaugh KJ, Hammond M, Myszka D, Sandel M. A Medical-legal partnership as a component of a palliative care model. J Palliative Med. 2010 Jan 5;13(1):15-8.

16. Ryan AM, Dachille C, Wolf D, et al. Income and health: Dynamics of employment and the safety Net. In: Tobin Taylor E, Lawton E, Conroy K, et al, editors. Poverty, health and law: Readings and cases for medical-legal partnership. Durham (NC): Carolina Academic Press; 2011. p. 189-224.

17. Tobin Tyler E, Conroy K, Fu C, Sandel M. Housing: The intersection of affordability, safety and health. In: Tobin Taylor E, Lawton E, Conroy K, et al, editors. Poverty, health and law: Readings and cases for medical-legal partnership. Durham (NC): Carolina Academic Press; 2011. p. 225-274.

18. Garg A, Toy S, Tripodis Y, Silverstein M, Freeman E. Addressing social determinants of health at well child care visits: A cluster RCT. Pediatrics. 2015 Feb 2;135(2):296-304.

19. National Association of Community Health Centers. PRAPARE [updated 2016; cited 2019 Nov 13]. Available from: www.nachc.org/research-and-data/prapare

20. Billioux A, Verlander K, Anthony S, et al. Standardized screening for health-related social needs in clinical settings: The Accountable Health Communities Screening Tool. NAM Perspectives. Discussion Paper, National Academy of Medicine, Washington (DC), 2017.

21. The Health Leads Screening Toolkit. Health Leads [updated 2018; cited 2019 Nov 13]. Available from: https://healthlead susa.org/resources/the-health-leads-screening-toolkit/

22. MLP legal needs screening tool available for download. National Center for Medical-Legal Partnership [updated 2015; cited 2019 Nov 13]. Available from: https://medical-legal partnership.org/screening-tool/

23. Screening Tool Finder. Screening time. American Academy of Pediatrics Screening Technical Assistance \& Resource Center [updated 2017; cited 2019 Nov 11]. Available from: https:// screeningtime.org/star-center/\#/screening-tools\#top

24. Dean B, Rethy J, Cilenti E, et al. Social determinants of health in an urban, low income pediatric population: A descriptive secondary analysis. Poster presented at the 2019 MedStarGeorgetown Summer Student Capstone. Washington (DC), Oct 10, 2019.

25. Hagan JF, Shaw JS, Duncan PM, editors. Bright Futures: Guidelines for health supervision of infants, children, and adolescents [pocket guide]. 4th ed. Elk Grove Village (IL): American Academy of Pediatrics; 2017

26. Baer TE, Gottlieb L, Sandel M. Addressing social determinants of health in the adolescent medical home. Curr Opin Pediatr 2013 Aug;25(4):447-53.

27. Barton LR, Parke KA, White CL. Screening for the social and behavioral determinants of health at a school-based clinic. J Pediatr Health Care. 2019 Mar 19;33(5):537-44.

28. Social Needs Screening Tool Comparison Table. SIREN. University of California, San Francisco [cited 2020 Dec 10]. Available from: https://sirenetwork.ucsf.edu/SocialNeeds ScreeningToolComparisonTable 